\title{
The Taxonomy of Brazilian Insects Vectors of Transmissible Diseases (1900-2000) - Then and Now
}

\author{
Nelson Papavero/ ${ }^{+}$, José Henrique Guimarães* \\ Instituto de Ciências Biológicas e Ambientais, Universidade Santa Úrsula, Rua Fernando Ferrari 75, 22231-040 \\ Rio de Janeiro, RJ, Brasil *Seção de Parasitoses, Instituto Biológico, Secretaria da Saúde do \\ Estado de São Paulo, São Paulo, SP, Brasil
}

\begin{abstract}
A brief historical overview is given of the most relevant taxonomic studies of insect groups vectors of transmissible diseases in Brazil, from the "heroic" times of the foundation of the Instituto Oswaldo Cruz in Rio de Janeiro up to the present. The following orders are considered: Phthiraptera (Anoplura, Amblycera and Ischnocera), Hemiptera (Reduviidae: Triatominae), Siphonaptera and Diptera (Culicidae, Ceratopogonidae, Psychodidae: Phlebotominae, Simuliidae, Tabanidae, Chloropidae and Muscidae). The most important Brazilian collections of each group are cited.
\end{abstract}

Key words: Brazil - insect vectors - taxonomy - history of studies - 20th century

\section{PHTHIRAPTERA}

Three suborders occur in Brazil: Anoplura, Amblycera, and Ischnocera, the latter two united before under the Order Mallophaga, which Lyal (1985) showed to be paraphyletic.

Anoplura - Over 550 species in 49 genera and 15 families are known in the world. Hopkins (1949) presented a list of the hosts of all the species of Anoplura described until then. The family classification was studied by Kim and Ludwig (1978), and Kim (1988) studied the evolutionary parallelism in Anoplura and eutherian mammals. Barker (1994) published the phylogeny and classification, origins and coevolution of host associations of the lice. Durden and Musser (1994a,b) produced a checklist for the species of the world, with a list of the hosts. For the taxonomy of the world Anoplura, the works of Ferris $(1919,1921,1951)$ are still the standard references. The study of this group among us had its main authority in FL Werneck (1932a, 1933, 1934, 1937, 1952, 1953a,b, 1955), researcher of the Instituto Oswaldo Cruz. The Haematopinidae parasitize ungulates; the Linognathidae, dogs and ruminants; the Pediculidae, primates; the Hoplopleuridae are in general parasites of rodents; the Echinophthiridae parasitize marine mammals; and the Neolignathidae are parasites of insectivorous mammals. There are no Anoplura parasitic upon birds.

\footnotetext{
${ }^{+}$Corresponding author. Fax $+55-21-557.7854$.

*CNPq fellow

Received 7 August 2000

Accepted 4 September 2000
}

Amblycera - The Amblycera are ectoparasites of birds, marsupials, carnivores and rodents. Clay's works $(1969,1970)$ are classical references for this group. In Brazil, Werneck (1948) contributed to our knowledge of the Amblycera of mammals.

Ischnocera - Over 600 species, in 106 genera distributed among three families are known for the world. The only monograph available for Brazilian Ischnocera parasitic on mammals is still Werneck's treatise $(1948,1950)$.

A basic work on all the Phthiraptera of Brazil (and all other arthropods) of veterinary importance is being prepared by Guimarães, Tucci, BarrosBattesti ("Ectoparasitas de Importância Veterinária", manusc. in preparation).

There are no large and organized collections of this order in Brazil, except for those of the Instituto Oswaldo Cruz and the Museu de Zoologia da Universidade de São Paulo.

\section{HEMIPTERA (REDUVIIDAE, TRIATOMINAE)}

Taxonomically speaking, this is by far the best known group of insects of medical and veterinary importance, whose study has been traditional at the Instituto Oswaldo Cruz throughout this century. Two monumental works on these insects, vectors of Chagas disease, were prepared by Lent and Wygodzinsky (1979) and most recently by Carcavallo et al. (1998). All the information available is given in those outstanding revisions.

\section{SIPHONAPTERA}

The pioneer study of Brazilian Siphonaptera was undertaken by AR Cunha, in a thesis prepared in the Instituto Oswaldo Cruz, and published in 1914. In 1946 appeared the classical monograph by Lima and Hathaway, another contribution from 
the same Institute. Hopkins and Rothschild (19531971) published a monograph of the order, based on the Rothschild collection. Holland (1964) contributed to our knowledge of the evolution, classification and host relationships of the Siphonaptera. The most recent survey of the fleas of Brazil was prepared by Linardi and Guimarães (2000), in whose book 50 species, distributed among 20 genera and 8 families, are treated (cf. Table I). In addition to the taxonomy of the group, the authors dealt with the parasitological importance of fleas, the methods of study, the interactions fleas/hosts, considering also the biology, control, morphology and systematics of the Siphonaptera; in appendices they included the geographic distribution of the species and subspecies of fleas per Brazilian state and a list of their known hosts.

Besides the collection of the Instituto Oswaldo Cruz, where the Costa Lima collection is housed, the most important collections of fleas are deposited in the Museu de Zoologia, Universidade de São Paulo, in São Paulo (organized by Lindolpho Rocha Guimarães) and in the Departamento de Parasitologia, Instituto de Ciências Biológicas, Universidade Federal de Minas Gerais, Belo Horizonte (organized by Pedro Marcos Linardi).

\section{DIPTERA}

From the publication of the tenth edition of Linnaeus' Systema Naturae, in 1758, up to the first four years of the 20th century, 40 authors (C Linnaeus, C Linnaeus Jr, JC Fabricius, PA Latreille, KP Thunberg, WF Erichson, JAM Perty, CRW Wiedemann, FE Guérin-Méneville, GA Olivier, JB Robineau-Desvoidy, PJM Macquart, $\mathrm{CH}$ Blanchard, JA Laboulbène, JMF Bigot, JO Westwood, F Walker, RA Philippi, CG Thomson, FM Brauer, CEA Gerstaecker, H Loew, J Mik, V von Roeder, E Rübsaamen, IR Schiner, D Bilimek, the brothers Félix and Enrique Lynch Arribálzaga, C Rondani, L Bellardi, E Giglio-Tos, H Weyenbergh, FM van der Wulp, Fritz Müller, Emil A Goeldi, EE Austen, CR Osten Sacken, SW Williston and JM Aldrich) have studied the taxonomy of Neotropical Diptera. The types of the species were deposited in the various museums of Europe and the United States (cf. Papavero, 19711973). In Brazil, up to the foundation of the Instituto Oswaldo Cruz, practically there existed neither collections nor specialized literature. In the turn of the century (1900-1901), the first catalogue of Neotropical Diptera was published by WD Hunter, albeit incomplete, as it only contemplated

TABLE I

Families, Subfamilies, Tribes and Genera of Brazilian Siphonaptera (number of species in parentheses) (after Linardi \& Guimarães 2000)

\begin{tabular}{|c|c|c|c|}
\hline Family & Subfamily & Tribe & Genus \\
\hline Pulicidae (5) & $\begin{array}{l}\text { Pulicinae (1) } \\
\text { Xenopsyllinae (2) } \\
\text { Archaepsyllinae (2) }\end{array}$ & Pulicini & $\begin{array}{l}\text { Pulex }(1) \\
\text { Xenopsylla }(2) \\
\text { Ctenocephalides (2) }\end{array}$ \\
\hline Tungidae (7) & & & $\begin{array}{l}\text { Tunga }(5) \\
\text { Hectopsylla }(1) \\
\text { Rhynchopsyllus }(1)\end{array}$ \\
\hline Ceratopsyllidae (1) & & & Notopsyllus (1) \\
\hline Leptopsyllidae (1) & & & Leptopsylla (1) \\
\hline Ischnopsyllidae (5) & & & $\begin{array}{l}\text { Hormopsylla }(1) \\
\text { Myodopsylla }(1) \\
\text { Ptilopsylla }(1) \\
\text { Sternopsylla }(1) \\
\text { Rothschildopsylla }(1)\end{array}$ \\
\hline Stephanocircidae (5) & $\begin{array}{l}\text { Craneopsyllinae (1) } \\
\text { Ctenophthalminae (4) }\end{array}$ & Tritopsyllini (4) & $\begin{array}{l}\text { Craneopsylla }(1) \\
\text { Adoratopsylla (2) } \\
\text { Tritopsylla }(2)\end{array}$ \\
\hline Rhopalopsyllidae (26) & Rhopalopsyllinae (26) & $\begin{array}{l}\text { Rhopalopsyllini (11) } \\
\text { Polygenini (15) }\end{array}$ & $\begin{array}{l}\text { Rhopalopsyllus (7) } \\
\text { Gephyropsylla (1) } \\
\text { Hechtiella (3) } \\
\text { Neotropopsylla (1) } \\
\text { Polygenis (14) }\end{array}$ \\
\hline
\end{tabular}


the Nematocera and part of the Brachycera (only the Homoeodactyla and the Mydidae). Between 1902 and 1910, Kolomán Kertész published his world catalogue of Diptera, which was also left incomplete.

This was the picture met with by the researchers of the Instituto Oswaldo Cruz (and Emil August Goeldi in Belém, Pará), in the first years of the 20th century, when, pressed by serious problems of public health, they had to begin studying the Brazilian species of Diptera that were vectors of several diseases.

Culicidae - Of foremost importance were the mosquitoes. The pioneer studies of this family in Brazil were undertakewn by Goeldi (1902, 1904a,b, 1905) in Belém, Pará; by Bourroul (1904); and by several researchers in Rio de Janeiro, mainly at the Instituto Oswaldo Cruz, such as Oswaldo Cruz himself (1901, 1906, 1907a,b), Adolpho Lutz (1904, 1905b, 1921), Lutz and Neiva (1913), Neiva (1906, 1908a,b), Neiva and Pinto (1922a,b,c, 1923), Peryassú (1908, 1921a,b, 1922a,b, 1923a,b,c, 1925; about Peryassú's collection, now in the Museu Nacional do Rio de Janeiro, cf. Khoury 1995). Dyar (1928) wrote a monograph of the mosquitoes of the Americas. The first modern monograph on the Brazilian fauna was prepared by Lane (1953), who was also responsible for the formation of an extremely important collection in the now Faculdade de Saúde Pública da Universidade de São Paulo, later expanded by OP
Forattini, who also has contributed to our knowledge of this group (cf. Forattini 1962-1965, 1996). The knowledge of the species of mosquitoes grew rapidly, and catalogues had to be prepared, the most important one by Stone et al. (1959), with supplements by Stone (1961, 1963, 1967, 1970, 1971) and its second revised edition by Knight and Stone (1977), followed by supplements sponsored by Knight (1978) and Ward (1992). The knowledge of immature stages of mosquitoes also grew rapidly and several important papers were published on this subject (e. g., Darsie Jr \& Clark-Gill 1982, González \& Darsie Jr 1996). For the identification of adults of mosquito genera of the world Rueda et al. prepared a key, appeared in CD-Rom form (1998). Consoli and Oliveira, following the tradition of the Instituto Oswaldo Cruz, prepared a basic work on Brazilian mosquitoes of sanitary importance (1994). Many sizable collections exist in the country, some of which have been catalogued (e. g., Forattini et al. 1970-1973; collection of the Faculdade de Saúde Pública da Universidade de São Paulo); Guedes et al. (1965, 1978); MarchonSilva et al. (1996; types in the Instituto Oswaldo Cruz); Wilkem et al. (1980), and Xavier (1973) and Xavier et al. (1989) (mosquito types of Brazil).

The most recent catalogue of this family for the Neotropical Region, with an extensive list of references, was published by Guimarães (1997), including 1,013 species (cf. Table II).

TABLE II

Subfamilies, Tribes, Genera and Subgenera of Neotropical Culicidae (number of species in parentheses) (after Guimarães 1997)

\begin{tabular}{|c|c|c|c|}
\hline Subfamily & Tribe & Genus & Subgenus \\
\hline Anophelinae (95) & & Anopheles (91) & $\begin{array}{l}\text { Anopheles }(45) \\
\text { Kerteszia }(12) \\
\text { Lophodomyia }(6) \\
\text { Nyssorhynchus }(28) \\
\text { Chagasia }(4)\end{array}$ \\
\hline Culicinae (908) & $\begin{array}{l}\text { Aedomyiini (1) } \\
\text { Aedini (274) }\end{array}$ & $\begin{array}{l}\text { Haemagogus (28) } \\
\text { Psorophora (44) }\end{array}$ & $\begin{array}{l}\text { Aedomyia }(1) \\
\text { Aedimorphus }(1) \\
\text { Aztecaedes }(1) \\
\text { Gymnometopa }(1) \\
\text { Howardina }(34) \\
\text { Kompia }(1) \\
\text { Ochlerotatus }(63) \\
\text { Protomacleaya }(36) \\
\text { Stegomyia }(2) \\
\text { Conopostegus }(4) \\
\text { Haemagogus }(24) \\
\text { Grabhamia }(14) \\
\text { Janthinosoma }(20) \\
\text { Psorophora }(10)\end{array}$ \\
\hline
\end{tabular}




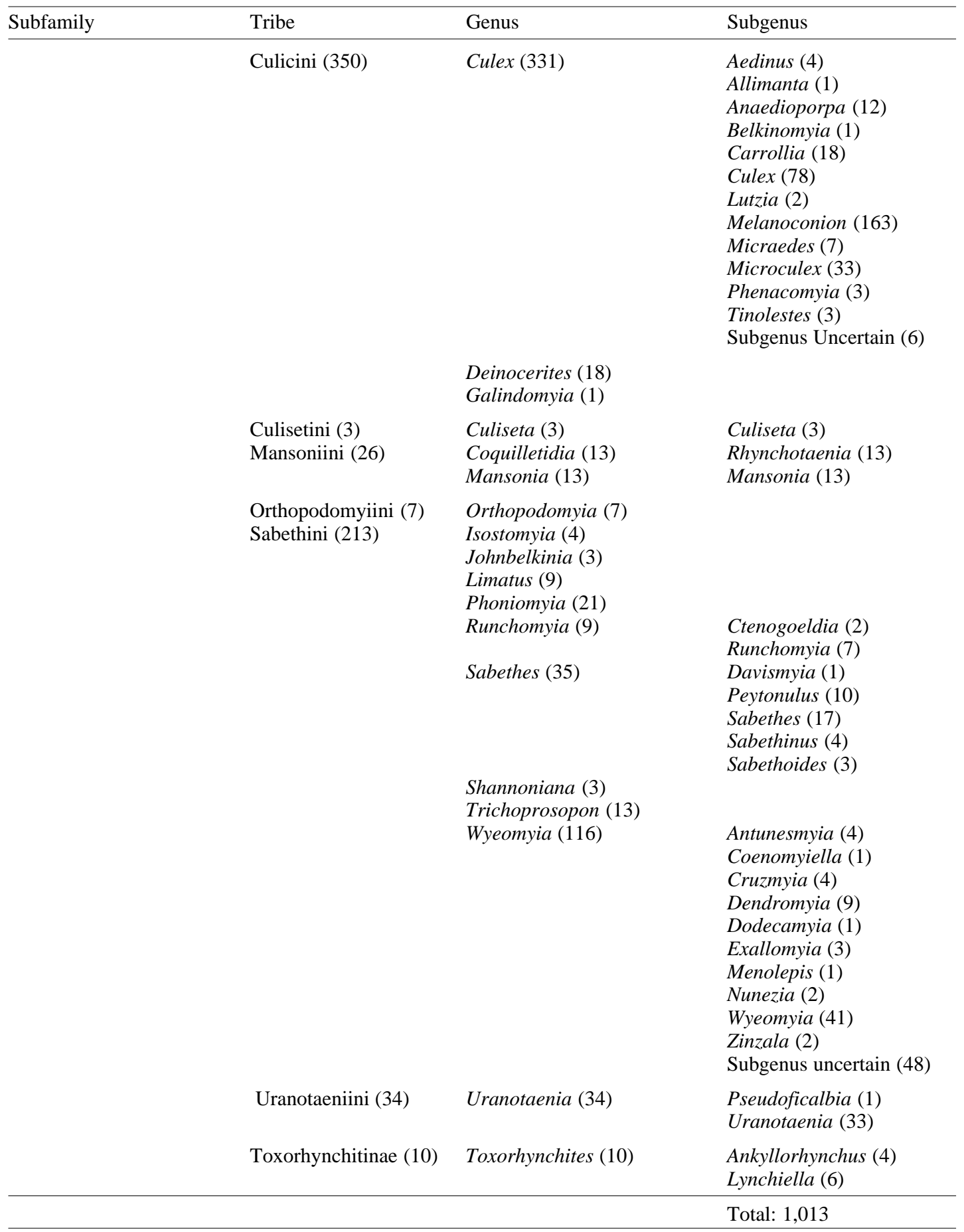

Ceratopogonidae - As with the Culicidae, ceratopogonid studies begun in Brazil at the Instituto Oswaldo Cruz, through the contributions of Lutz (1913b, 1914b). The species of Culicoides were revised by Forattini (1957) and later by Wirth et al. (1988). The genera of the family were reviewed by Wirth et al. (1974).
Wirth's catalogue of the Neotropical species (1974) was superseded by the world catalogue of Borkent and Wirth (1997), which lists 920 species from the Neotropics (cf. Table III). Kettle (1977) wrote a comprehensive essay about the biology and bionomics of blood sucking ceratopogonids (Table III). 
TABLE III

Subfamilies, Tribes and Genera of Neotropical Ceratopogonidae (number of species in parentheses) (adapted from Spinelli, 1998)

\begin{tabular}{|c|c|c|}
\hline Subfamily & Tribe & Genus \\
\hline Leptoconopinae (12) & & Leptoconops (12) \\
\hline Forcipomyiinae (213) & & $\begin{array}{l}\text { Atrichopogon }(65) \\
\text { Forcipomyia }(148)\end{array}$ \\
\hline Dasyheleinae (45) & & Dasyhelea (45) \\
\hline \multirow[t]{7}{*}{ Ceratopogoninae (660) } & Culicoidini (266) & $\begin{array}{l}\text { Culicoides }(265) \\
\text { Paradasyhelea }(1)\end{array}$ \\
\hline & Ceratopogonini (180) & $\begin{array}{l}\text { Allohelea }(1) \\
\text { Alluaudomyia }(19) \\
\text { Austrohelea }(1) \\
\text { Baseodasymyia }(2) \\
\text { Baeohelea }(1) \\
\text { Bahiahelea }(1) \\
\text { Borkenthelea }(1) \\
\text { Brachypogon }(10) \\
\text { Cacaohelea }(1) \\
\text { Diaphanohelea }(4) \\
\text { Downeshelea }(17) \\
\text { Echinohelea }(11) \\
\text { Fittkauhelea }(1) \\
\text { Isthmohelea }(1) \\
\text { Leptohelea }(1) \\
\text { Macrurohelea }(11) \\
\text { Monohelea }(12) \\
\text { Nannohelea }(1) \\
\text { Nottohelea }(2) \\
\text { Parabezzia }(22) \\
\text { Parasitobezzia }(1) \\
\text { Schizonyxhelea }(1) \\
\text { Stilobezzia }(58)\end{array}$ \\
\hline & Heteromyiini (30) & $\begin{array}{l}\text { Clinohelea }(13) \\
\text { Heteromyia }(11) \\
\text { Pellucidomyia }(4) \\
\text { Physohelea }(2)\end{array}$ \\
\hline & Sphaeromyiini (24) & $\begin{array}{l}\text { Austrosphaeromias (2) } \\
\text { Groganhelea (1) } \\
\text { Johannsenomyia (2) } \\
\text { Lanehelea }(2) \\
\text { Mallochohelea }(5) \\
\text { Neobezzia }(8) \\
\text { Nilobezzia }(3) \\
\text { Sphaerohelea }(1)\end{array}$ \\
\hline & Palpomyiini (106) & $\begin{array}{l}\text { Amerohelea }(11) \\
\text { Bezzia }(43) \\
\text { Clastrieromyia (4) } \\
\text { Pachyhelea (2) } \\
\text { Palpomyia (43) } \\
\text { Phaenobezzia (3) }\end{array}$ \\
\hline & Stenoxenini (54) & $\begin{array}{l}\text { Paryphoconus (39) } \\
\text { Stenoxenus (15) }\end{array}$ \\
\hline & & Total: 930 \\
\hline
\end{tabular}


Psychodidae (Phlebotominae) - Lutz and Neiva (1912), and Lima (1932), and other authors, were responsible for the first studies of phlebotomine sandflies in Brazil. The knowledge of the group grew exponentially, and modern contributions include the catalogue of the subfamily by Martins et al. (1978), the main tentatives of a classification by Theodor (1965), Forattini (1971, 1973), Young and Fairchild (1974), Lewis et al. (1977) and Williams (1993). Revisions were made by Young and Fairchild (1974) and Young and Duncan (1994). An article on the biology of Phlebotominae in relation to leishmaniasis was prepared by Lewis (1974). The most important collections are deposited in the Universidade Federal de Minas Gerais in Belo Horizonte, Faculdade de Saúde Pública, Universidade de São Paulo in São Paulo, Instituto Oswaldo Cruz in Rio de Janeiro and Museu de Zoologia, Universidade de São Paulo in São Paulo.

Simuliidae - Around 1500 species of blackflies are known in the world, 250 of which in the Neotropical Region. The family inludes only two subfamilies: Parasimuliinae (with 1 genus), and Simuliinae, with two tribes - Prosimuliini (with 16 genera) and Simuliinae (with 2 genera, but the genus Simulium with 45 subgenera, comprising approximately $90 \%$ of the species of the family).

As usual with medically important Diptera, the first contributions to the taxonomy of this group in Brazil were made by Lutz (1909, 1910, 1917). There is no recent, comprehensive revision of this group for the Neotropics. Coscarón (1987) published, however, an important paper, in which he reviewed most of the species described by earlier authors, and examined material collected by him in Brazil in the most important localities explored by those authors. Vulcano's catalogue of the Neotropical species (1967) is now outdated; it was replaced by the world catalogue of Simuliidae by Crosskey (1981). For the biology of this group, see, for example, Wenk (1981).

A really good collection of this family is still lacking in Brazil. The most important ones, however, are in the Instituto Oswaldo Cruz and in the Museu de Zoologia, Universidade de São Paulo.

Tabanidae - Not surprisingly, Adolpho Lutz was the responsible for the commencement of the studies of horseflies in Brazil (Lutz 1905a, 1909a,b, 1911, 1912, 1913a, 1913c, 1914a, 1914c, 1915, Lutz \& Neiva 1914), inclusive of their immature stages (a study which, unfortunately, never had followers among us), most of the species superbly illustrated in colours, of a quality never more equalled; his collection was throroughly revised by Fairchild (1961). Many other authors contributed to the knowledge of the taxonomy of the group. In 1969 Fairchild prepared an excellent key to the Neotropical genera, preliminary to his catalogue of the species appeared in 1971. His keys served as a basis for Coscarón and Papavero's manual for the Neotropical genera (1993) and the most recent catalogue was sponsored by Fairchild and Burger (1994).

Important collections, besides the historical Lutz material at the Instituto Oswaldo Cruz, exist in the Museu de Zoologia, Universidade de São Paulo (in São Paulo), Museu Paraense Emílio Goeldi (Belém, Pará) and Instituto Nacional de Pesquisas da Amazônia (Manaus, Amazonas).

Chloropidae - It has recently been demonstrated that representatives of the genera Hippelates and Liohippelates are associated with Brazilian purpuric fever (Paganelli \& Sabrosky 1993, Tondella et al. 1994). No recent revision of the species of those chloropid genera exist.

Muscidae (Musca domestica, Stomoxys calcitrans) - Three "classics" must be consulted with reference to the two mentioned species of Muscidae: Greenberg (1971), Zumpt (1973) and Skidmore (1985).

Of general interest for all families of Diptera, should be cited Sabrosky's recently published book on family-names in Diptera, with many novelties about nomenclature (1998, in CD-Rom 1999).

\section{REFERENCES}

Barker SC 1994. Phylogeny and classification, origins and evolution of host associations of lice. Intern $J$ Parasitol 24: 1285-1291.

Borkent A, Wirth WW 1997. World species of biting midges (Diptera: Ceratopogonidae). Bull Am Mus Nat Hist 233: 1-257.

Bourroul C 1904. Mosquitos do Brasil, PhD Thesis, JB de Oliveira Costa, Salvador, Bahia.

Carcavallo RV, Girón IG, Jurberg J, Lent H 1998. Atlas of Chagas' Disease Vectors in the Americas. Atlas dos Vetores da Doença de Chagas nas Américas, 3 vols, Editora Fiocruz, Rio de Janeiro.

Clay T 1969. A key to the genera of Menoponidae (Amblycera: Mallophaga: Insecta). Bull BMNH Ent 11: 189-244.

Clay T 1970. The Amblycera (Phthiraptera: Insecta). Bull BMNH Ent. 25: 73-98.

Consoli RAGB, Oliveira RL de 1994. Principais Mosquitos de Importância Sanitária no Brasil, Editora Fiocruz, Rio de Janeiro, 228 pp.

Coscarón S 1987. El Género Simulium Latreille en la Región Neotropical: Análisis de los Grupos Supraespecíficos, Especies que los Integran y Distribución Geográfica (Simuliidae, Diptera, Insecta), Museu Paraense Emílio Goeldi, Belém, 111 pp.

Coscarón S, Papavero N 1993. An Illustrated Manual for the Identification of the Neotropical Genera and Subgenera of Tabanidae (Diptera), Museu Paraense Emílio Goeldi, Belém, 150 pp. 
Crosskey RW 1981. An annotated checklist of the world black flies (Diptera: Simuliidae). In KC Kim, RW Merritt, Blackflies: Ecology, Population Management and Annotated World List, Pennsylvania Sate University Press, p. 425-520.

Cruz OG 1901. Contribuição para o estudo dos culicidos do Rio de Janeiro. Brazil méd 15: 423-426.

Cruz OG 1906. Um novo genero brasileiro da sub-familia Anophelina. Brazil méd 20: 199-200.

Cruz OG 1907a. Um novo genero brasileiro da sub-familia Anophelinae. Brazil méd 21: 271-273.

Cruz OG 1907b. Uma nova especie do genero Psorophora. Brazil méd 21: 329-330.

Cunha R de A 1914. Contribuição para o Estudo dos Sifonápteros do Brasil, Thesis, Instituto Oswaldo Cruz \& Rodrigues \& Cia., Rio de Janeiro, 212 pp. (Also publ. in Mem Inst Oswaldo Cruz 6, 1914).

Darsie Jr RF, Clark-Gill S 1982. Key to mosquito genera of the New World, fourth-stage larvae. In DP Furman, EP Catts, Manual of Medical Entomology, Press Syndicate of the University of Cambridge, USA, p. 93-95, 101-103.

Durden LA, Musser GG 1994a. The sucking lice (Insecta, Anoplura) of the world: A taxonomic checklist with records of mammalian hosts and geographical distribution. Bull Am Mus Nat Hist 128: 1-90.

Durden LA, Musser GG, 1994b. The mammalian hosts of the sucking lice (Anoplura) of the world: A hostparasite list. Bull Soc Vector Ecol 19: 130-168.

Dyar HG 1928. The mosquitoes of the Americas. Carnegie Inst Wash Publ 357: 1-616.

Fairchild GB 1961. The Adolpho Lutz collection of Tabanidae (Diptera). I. The described genera and species, condition of the collection, and selection of lectotypes. Mem Inst Oswaldo Cruz 59: 185-249.

Fairchild GB 1969. Notes on Neotropical Tabanidae. XII. Classification and distribution, with keys to genera and subgenera. Arq Zool São Paulo 17: 199-255.

Fairchild GB 1971. Family Tabanidae. In N Papavero, A Catalogue of the Diptera of the Americas South of the United States 28: 1-163, Museu de Zoologia, Universidade de São Paulo, São Paulo.

Fairchild GB, Burger JF 1994. A catalog of the Tabanidae (Diptera) of the Americas south of the United States. Mem Am Ent Inst 55: 249 pp.

Ferris GF 1919. A catalogue and host list of the Anoplura. Proc Calif Acad Sci 6: 129-213.

Ferris GF 1921. Contributions toward a monograph of the sucking lice. Part II. Stanford Univ Publs (Biol Sci) 2: 1-634.

Ferris GF 1951. The sucking lice. Mem Pacific Coast Ent Soc 1: 1-320.

Forattini OP 1957. Culicoides da Região Neotropical (Diptera, Ceratopogonidae). Arq Fac Hig Saúde Públ Univ São Paulo 11: 161-526.

Forattini OP 1962-1965. Entomologia Médica. Vol. I, Parte Geral. Diptera: Anophelini, 662 pp., 1962; Vol. II, Culicini: Aedes e Psorophora, 506 pp., 1962; Vol. III, Culicini: Haemagogus, Mansonia, Culiseta, Sabethini, Toxorhynchitini, Arboviroses. Filariose bancroftiana. Genética, 415 pp., 1965, Faculdade de Higiene e Saúde Pública, Universidade de São
Paulo, São Paulo.

Forattini OP 1971. Sobre a classificação da subfamília Phlebotominae nas Américas (Diptera, Psychodidae). Papéis Avulsos Zool São Paulo 24: 93-111.

Forattini OP 1973. Entomologia Médica. Vol. 4, Psychodidae, Phlebotominae, Leishmanioses, Bartonelose, Edgar Blücher \& Editora da Universidade de São Paulo, São Paulo, 658 pp.

Forattini OP 1996. Culicidologia Médica. Vol. 1, Principios Gerais, Morfologia, Glossário Taxonômico, Editora da Universidade de São Paulo, São Paulo, 548 pp.

Forattini OP, Rabello EX, Cotrim MD 1971-1973. Catálogo das coleções entomológicas da Faculdade de Saúde Pública da Universidade de São Paulo. Culicidae. Revta Saúde Públ São Paulo 4(nº esp): 1-100, 1971; 7(no esp): 453-479, 1973.

Goeldi EA 1902. Os Mosquitos do Pará, Encarados como uma Calamidade Pública. Diário Oficial, Belém do Pará, 58 pp. (Also publ. in Brazil méd 16: 480-482; 17: 5-8, 25-28, 35-38, 43-45, 1902).

Goeldi EA 1904a. Os mosquitos no Pará. Resumo provisorio dos resultados da campanha de experiências executadas em 1903 especialmente em relação às especies Stegomyia fasciata e Culex fatigans, sob o ponto de vista sanitario. Bol Mus Goeldi 4: 129.

Goeldi EA 1904b. Stegomyia fasciata, der das Gelbfieber übertragende Mosquito und der gegenwärtige Stand der Kenntnis über die Ursache dieser Krankheit. Vortrag aud fem Internationale Zoologen-Kongress in Bern, Sektion für Allgemene Zoologie, 15, August 1904

Goeldi EA 1905. Os mosquitos no Pará. Reunião de quatro trabalhos sobre os mosquitos indígenas, principalmente as especies que molestam o homem. Mem Mus Goeldi 4: 1-152.

González R, Darsie Jr RF 1996. Clave ilustrada para la determinación genérica de larvas de Culicidae de Colombia y del Nuevo Mundo. Bol Mus Ent Univ Valle 4: 21-37.

Greenberg, B 1971. Flies and Disease. Classification and Biotic Associations, Princeton University, New Jersey, 856 pp.

Guedes AS, Souza MA de, Maciel CS, Xavier SH 1965. Catálogo ilustrado dos mosquitos da coleção do Instituto Nacional de Endemias Rurais. I. Gênero Psorophora Robineau-Desvoidy, 1827. Revta Bras Malariol Doenç Trop 17: 3-14.

Guedes AS, Xavier SH, Mascarenhas CS, Ferreira MFL, 1978. Catálogo da coleção do Laboratório de Entomologia do Centro de Pesquisas René Rachou, Fundação Oswaldo Cruz. II. Gêneros Aedeomyia Theobald 1901, Orthopodomyia Theobald 1904 (Diptera, Culicidae). Ci Cult 30: 1111-1116.

Guimarães JH 1997. Systematic Database of the Diptera of the Americas South of the United States. Family Culicidae, Editora Plêiade \& Fundação de Amparo à Pesquisa do Estado de São Paulo, São Paulo, 286 pp.

Holland GP 1964. Evolution, classification, and the host relationships of Siphonaptera. Annual Rev Ent 9: 123-146. 
Hopkins GHE 1949. The host-associations of the lice of mammals. Proc Zool Soc London 11: 387-604.

Hopkins GHE, Rothschild M 1953. An Illustrated Catalogue of the Rothschild Collection of Fleas (Siphonaptera) in the British Museum (Natural History), Vol. I, Tungidae and Pulicidae, British Museum (Natural History), London, 361 pp.

Hopkins GHE, Rothschild M 1956. An Illustrated Catalogue of the Rothschild Collection of Fleas (Siphonaptera) in the British Museum (Natural History), Vol. II, Cotopsyllidae, Vermipsyllidae, Stephanocircidae, Ischnopsyllidae, Hypsophthalmidae, and Xiphiopsyllidae, British Museum (Natural History), London, $445 \mathrm{pp}$.

Hopkins GHE, Rothschild M 1962. An Illustrated Catalogue of the Rothschild Collection of Fleas (Siphonaptera) in the British Museum (Natural History). With Keys and Short Descriptions for the Identification of Families, Genera, Species and Subspecies of the Order. Vol. III, Hystricopsyllidae (Anomiopsyllinae, Hystricopsyllinae, Neopsyllinae, Rhadinopsyllinae and Stenoponiinae), British $\mathrm{Mu}-$ seum (Natural History), London, 560 pp.

Hopkins GHE, Rothschild M 1966. An Illustrated Catalogue of the Rothschild Collection of Fleas (Siphonaptera) in the British Museum (Natural History). With keys and Short Descriptions for the Identification of Families, Genera, Species and Subspecies of the Order. Vol. IV, Ctenophthalmidae,Dinopsyllidae, Doratopsyllidae and Listropsyllidae, British Museum (Natural History), London, 549 pp.

Hopkins GHE, Rothschild M 1971. An Illustrated Catalogue of the Rothschild Collection of Fleas (Siphonaptera) in the British Museum (Natural History). With Keys and Short Descriptions for the Identification of Families, Genera, Species and Subspecies of the Order. Vol. V, Leptopsyllidae and Ancistropsyllidae, British Museum (Natural History), London, $530 \mathrm{pp}$.

Hunter WD 1900-1901. A catalogue of the Diptera of South America. Part I. Bibliography and Nematocera. Part II. Homodactyla and Mydiadae [sic]. Trans Am Ent Soc 26: 260-298, 1900; 27: 121-155, 1901.

Kertész K 1902a. Catalogus Dipterorum Hucusque Descriptorum, Vol. I, Museum Nationale Hungaricum, Budapestini, 339 pp.

Kertész K 1902b. Catalogus Dipterorum Hucusque Descriptorum, Vol. II, Museum Nationale Hungaricum, Budapestini, 359 pp.

Kertész K 1908. Catalogus Dipterorum Hucusque Descriptorum, Vol. III, Museum Nationale Hungaricum, Budapestini, 366 pp.

Kertész K 1909a. Catalogus Dipterorum Hucusque Descriptorum, Vol. IV, Museum Nationale Hungaricum, Budapestini, 349 pp.

Kertész K 1909b. Catalogus Dipterorum Hucusque Descriptorum, Vol. V, Museum Nationale Hungaricum, Budapestini, 199 pp.

Kertész K 1909c. Catalogus Dipterorum Hucusque Descriptorum, Vol. VI, Museum Nationale Hungaricum, Budapestini, $362 \mathrm{pp}$.

Kertész K 1910. Catalogus Dipterorum Hucusque
Descriptorum, Vol. VII, Museum Nationale Hungaricum, Budapestini, 470 pp.

Kettle DS 1977. Biology and bionomics of blood sucking ceratopogonids. Annual Rev Ent 22: 33-51.

Kim KC 1988. Evolutionary parallelism in Anoplura and eutherian mammals. Syst Assoc 37: 91-114.

Kim KC, Ludwig HW 1978. The family classification of the Anoplura. Syst Ent 3: 249-284.

Knight KL 1978. Supplement to a Catalog of the Mosquitoes of the World (Diptera, Culicidae). Entomological Society of America, Thomas Say Foundation Publ 6(Suppl.): 1-107.

Knight KL, Stone A 1977. A catalog of the mosquitoes of the world (Diptera, Culicidae) (2nd ed.). Entomological Society of America, Thomas Say Foundation Publ 6: $611 \mathrm{pp.}$

Khouri A 1995. Sobre a coleção de anophelineos brasileiros do Museu Nacional. Bol Mus Ent Univ Valle 3: 29-36.

Lane J 1953. Neotropical Culicidae, 2 vols, Universidade de São Paulo, São Paulo.

Lent H, Wygodzinsky P 1979. Revision of the Triatominae (Hemiptera, Reduviidae) and their significance as vectors of Chagas' disease. Bull Am Mus Nat Hist 163: 125-520.

Lewis DJ 1974. The biology of Phlebotominae in relation to leishmaniasis. Annual Rev Ent 19: 363-384.

Lewis DJ, Young DG, Fairchild GB, Minter DM 1977. Proposal for a stable classification of the Phlebotominae sandflies (Diptera: Psychodidae). Syst Ent 2: 319-332.

Lima AM da C 1932. Sobre os phlebotomos americanos (Diptera: Psychodidae). Mem Inst Oswaldo Cruz 26: 15-69.

Lima AM da C, Hathaway CR 1946. Pulgas. Bibliografia, Catálogo e Hospedadores, Monografias do Instituto Oswaldo Cruz, Imprensa Nacional, Rio de Janeiro, 522 pp.

Linardi PM, Guimarães LR 2000. Sifonápteros do Brasil, Museu de Zoologia da Universidade de São Paulo \& Fundação de Amparo à Pesquisa do Estado de São Paulo, São Paulo, 291 pp.

Lutz A 1904. Quadro dos generos da familia Culicidae (2 page folded table). In C Bourroul, q. $v$.

Lutz A 1905a. Beiträge zur Kenntniss der Brasilianischen Tabaniden. Revta Soc Scient São Paulo 1: 19-32.

Lutz A 1905b. Novas especies de mosquitos do Brasil. Imprensa méd São Paulo 13: 26-29, 65-69, 81-83, 101-104, 125-128, 169-172, 202-203, 269-271, 287290, 311-314, 347-350.

Lutz A 1909a. Collecção de tabánidas. In Instituto Oswaldo Cruz em Manguinhos, Instituto Oswaldo Cruz, Rio de Janeiro, p. 28-30.

Lutz A 1909b. Tabaniden Brasilien und einiger Nachbarstaaten. Zool Jahrb (Suppl. 10) 4: 619-692.

Lutz A 1909c. Contribuição para o conhecimento das especies brasileiras do gênero Simulium. Mem Inst Oswaldo Cruz 1: 124-146.

Lutz A 1910. Segunda contribuição para o conhecimento das especies brasileiras do gênero Simulium. Mem Inst Oswaldo Cruz 2: 213-267.

Lutz A 1911. List of Tabanidae. In Internationale Hy- 
giene-Ausstellung, Dresden, Instituto Oswaldo Cuz, em Manguinhos, Rio de Janeiro, p. 33-35.

Lutz A 1912. Contribuição para a estudo da biologia dos dipteros hematofagos. III. Sangue verde em tabanidas e outros dipteros. Mem Inst Oswaldo Cruz 4: 79-81.

Lutz A 1913a. Sobre a systematica dos tabanideos, subfamilia Tabaninae. Brasil méd 17: 486-490.

Lutz A 1913b. Contribuição para o estudo das ceratopogoninas hematofagas do Brazil. Parte sistematica. Segunda memoria. Mem Inst Oswaldo Cruz 5: 45-73.

Lutz A 1913c Tabanidas do Brasil e alguns Estados vizinhos. Tabaniden Brasiliens und einiger Nachbarstaaten. Mem Inst Oswaldo Cruz 5: 142-191.

Lutz A 1914a. Notas dipterologicas. Contribuição para o conhecimento dos primeiros estados de tabanideos brasileiros. Mem Inst Oswaldo Cruz 6: 43-49.

Lutz A 1914b. Contribuição para o estudo das ceratopogoninas hematofagas do Brazil. Terceira memoria. Aditamento terceiro e descrição de especies que não sugam sangue. Mem Inst Oswaldo Cruz 6: 81-99.

Lutz A 1914c. Ueber die Systematik der Tabaninae, Subfamilie der Tabanidae. Mem Inst Oswaldo Cruz 6: 163-168.

Lutz A 1915. Tabanidas do Brasil e alguns Estados vizinhos. Segunda memoria. Tabaniden Brasiliens und einiger Nachbarstaaten. Fortsetzung. Mem Inst Oswaldo Cruz 7: 51-119.

Lutz A 1917. Terceira contribuição para o conhecimento das especies brasileiras de Simulium. O piúm do norte (Simulium amazonicum). Mem Inst Oswaldo Cruz 9: 63-67.

Lutz A 1921. Culicideos (Systematica). Chave para os Culicideos. Folha méd 2: 161-163.

Lutz A, Neiva A 1911. Notas dipterolojicas. Dipterologische Mitteilungen. Mem Inst Oswaldo Cruz 3: 295-300.

Lutz A, Neiva A 1912. Contribuição para o conhecimento das especies do genero Phlebotomus existentes no Brasil. Mem Inst Oswaldo Cruz 4: 84-95.

Lutz A, Neiva A 1913. Contribuições para a biolojia das megarhininas com descrições de duas especies novas. Beiträge zur Biologie der Megarhinen und Beschreibung zweier neuen Arten. Mem Inst Oswaldo Cruz 5: 129-141.

Lutz A, Neiva A 1914. As Tabanidae do Estado do Rio de Janeiro. Ueber die Tabaniden des Staates Rio de Janeiro. Mem Inst Oswaldo Cruz 6: 69-80.

Lutz A, Araujo HC de S, Fonseca O da 1918. Viajem scientifica no Rio Paraná, e a Asunción com volta por Buenos Aires, Montevideo e Rio Grande. Mem Inst Oswaldo Cruz 10: 104-173.

Lyal CHC 1985. Phylogeny and classification of the Psocodea, with particular reference to the lice (Psocodea: Phthiraptera). Syst Ent 10: 145-165.

Marchon-Silva,V, Oliveira RL de, Almeida MD, Vasconcelos AS, Costa J 1996. The type specimens of mosquitoes (Diptera, Culicidae) deposited in the entomological collection of the Instituto Oswaldo Cruz, Rio de Janeiro, Brazil. Mem Inst Oswaldo Cruz 91: 471-478.
Martins AV, Williams P, Falcão AL 1978. American Sand Flies (Diptera: Psychodidae, Phlebotominae), Academia Brasileira de Ciências, Rio de Janeiro, 195 pp.

Neiva A 1906. Uma nova especie de anophelina brasileira. Brazil-méd 20: 288-289, ill. (Also sep. publ., 8, Besnard Frères, Rio de Janeiro, 8 pp, 1906, in the collection "Trabalhos do Instituto Oswaldo Cruz").

Neiva A 1908a. Contribuição ao estudo dos dipteros brasileiros. Uma nova especie de Sabethes. Brazilméd 22: 351-352.

Neiva A 1908b. As anophelinas brazileiras. Revta méd São Paulo 11: 455-459.

Neiva A, Pinto C 1922a. Contribuição para o conhecimento das anophelinas do estado de Mato Grosso, com a descripção de uma especie. Brazilméd 36: 321-322.

Neiva A, Pinto C 1922b. Considerações sobre o genero Cellia Theobald, com a descripção de uma nova especie. Brazil-méd 36: 355-357.

Neiva A, Pinto C 1922c. Comentarios sobre o genero Uranotaenia Arribálzaga [sic] 1891 com descripção de uma nova especie. Brazil-méd 36: 374.

Neiva A, Pinto C 1923. Sobre uma nova anophelina brazileira (Cellia cuyabensis nov. sp.). Brazil-méd 37: 235-236.

Paganelli CH, Sabrosky CW 1993. Hippelates flies (Diptera: Chloropidae) possibly associated with Brazilian purpuric fever. Proc Ent Soc Wash 95: 165174.

Papavero N 1971-1973. Essays on the History of Neotropical Dipterology, with Special Reference to Collectors (1750-1905), Vol. I, 216 pp., 1971; Vol. II, p.217-446, 1973, Museu de Zoologia, Universidadede São Paulo, São Paulo.

Peryassú AG 1908. Os Culicideos do Brazil, Rio de Janeiro, $407 \mathrm{pp}$.

Peryassú AG 1921a. Os anophelinos do Brazil. Arch Mus Nac Rio de Janeiro 23: 5-101.

Peryassú AG 1921b. Um novo anophelineo brasileiro. Folha méd 2: 141.

Peryassú AG 1922a. Uma nova especie de culicineo brasileiro. Folha méd 3: 117-118.

Peryassú AG 1922b. Duas novas especies de mosquitos do Brazil. Folha méd 3: 179.

Peryassú AG 1923a. Uma nova especie de mosquito do Brasil. Folha méd 4: 2.

Peryassú AG 1923b. Uma nova especie de anophelineo do genero Cyclolepteron. Folha méd 4: 68-69.

Peryassú AG 1923c. Catalogo das subfamilias, generos e especies, com sinonimias dos culicideos encontrados no Brasil. Folha méd 4: 74-76.

Peryassú AG 1925. Anopheles alagoani n. sp. Folha méd 6: 258-259.

Pinto C 1930. Arthropodes Parasitos e Transmissores de Doenças, Pimenta de Mello \& Cia, Rio de Janeiro, $395 \mathrm{pp}$.

Rueda LM, Stockwell SA, Pecor JE, Gaffingan TV 1998. Key to the mosquito genera of the world. Diptera Data Dissemination Disk 1. North American Dipterists Society, c/o Systematic Entomology Labo- 
ratory, USDA, NHB-168 Smithsonian, Washington, D. C. 20560.

Sabrosky CW, Thompson FC, Evenhuis NL 1998. Family-group names in Diptera. Diptera Data Dissemination Disk 1. North American Dipterists Society, c/ o Systematic Entomology Laboratory, USDA, NHB168 Smithsonian, Washington, D. C. 20560.

Sabrosky CW 1999. Family-group names in Diptera. An annotated catalog. Bibliography by F. Christian Thompson, Neal L. Evenhuis \& Curtis W. Sabrosky. Myia 10: 1-576.

Skidmore P 1985. The Biology of the Muscidae of the World, W. Junk Publishers, Dordrecht.

Spinelli G. R. 1998. Ceratopogonidae. In JJ Morrone, S Coscarón (eds), Biodiversidad de Artrópodos Argentinos. Una Perspectiva Biotaxonómica, Ediciones Sur, La Plata, p. 314-326.

Stone A 1961. A synoptic catalog of the mosquitoes of the world, Suppl. I (Diptera, Culicidae). Proc Ent Soc Wash 63: 29-52.

Stone A 1963. A synoptic catalog of the mosquitoes of the world, Suppl. II (Diptera, Culicidae). Proc Ent Soc Wash 65: 117-140.

Stone A 1967. A synoptic catalog of the mosquitoes of the world, Suppl. III (Diptera, Culicidae). Proc Ent Soc Wash 69: 197-224.

Stone A 1970. A synoptic catalog of the mosquitoes of the world, Suppl. IV (Diptera, Culicidae). Proc Ent Soc Wash 72: 137-171.

Stone A 1971. Corrections to the mosquito catalog supplements III and IV. Proc ent Soc Wash 73: 180.

Stone A, Knight KL, Starcke H 1959. A synoptic catalogue of the mosquitoes of the world (Diptera, Culicidae). Entomological Sociey of America. Thomas Say Found Publ 6: 1-358.

Theodor O 1965. On the classification of American Phlebotominae. J Med Ent 2: 171-187.

Tondella ML, Paganelli CH, Takano IMOA, Irino K, Brandileone MC, Mezzacapa Neto B, Vieira VS, Perkins BA 1994. Isolation of Haemophilus aegyptius associated with Brazilian purpuric fever, of Chloropidae (Diptera) of the genera Hippelates and Liohippelates. Rev Inst Med Trop São Paulo 3: 105-109.

Vulcano MA 1967. Family Simuliidae. In N Papavero, A Catalogue of the Diptera of the Americas South of the United States 16: 1-44, Departamento de Zoologia, Secretaria da Agricultura do Estado de São Paulo, São Paulo.

Ward RA 1992. Third supplement to "A Catalog of the mosquitoes of the world (Diptera, Culicidae)". Mosq Syst 24: 177-230.

Wenk P 1981. Bionomics of adult blackflies. In Laird, Blackflies, Academic Press, London, p. 259-279.

Werneck FL 1932a. Nova espécie de Anoplura. Mem Inst Oswaldo Cruz, 26: 235.

Werneck FL 1932b. Sobre uma nova especie de Hopopleura (Nota previa). Revta Méd Cirúrg Bras 12: 345-346.

Werneck FL 1933. Sobre duas especies de Anoplura encontradas em ratos sylvestres do Brasil. Mem Inst Oswaldo Cruz 27: 405-415.
Werneck FL 1934. Sobre duas especies de Anoplura encontradas em ratos sylvestres do Brasil. Mem Inst Oswaldo Cruz 27: 407-421.

Werneck FL 1937. Algumas especies e subespecies novas de Anoplura. Mem Inst Oswaldo Cruz 32: 391410.

Werneck FL 1941. De um estranho parasito do cão (Insecta, Mallophaga). Revta Bras Biol 1: 47-55.

Werneck FL 1942. Pterophthirus imitans n. sp. Revta Bras Biol 2: 317-320.

Werneck FL 1948. Os Malófagos de Mamíferos. Parte I. Amblycera e Ischnocera (Philopteridae e Parte de Trichodectidae), Edição da Revista Brasileira de Biologia, Rio de Janeiro, 243 pp.

Werneck FL 1950. Os Malófagos de Mamíferos. Parte II. Ischnocera (Continuação de Trichodectidae e Rhynchophthirina), Edição do Instituto Oswaldo Cruz, Rio de Janeiro, 207 pp.

Werneck FL 1952. Contribuição ao conhecimento dos anopluros. Revta Bras Biol 12: 69-78, 201-210, 421431.

Werneck FL 1953. Contribuição ao conhecimento dos anopluros. Revta Bras Biol 13: 53-64.

Werneck FL 1954. Contribuição ao conhecimento dos anopluros. Revta Bras Biol 14: 109-117.

Werneck FL 1955. Novo anopluro do leão marinho. Revta Bras Biol 15: 419-421.

Wilkem MF, Xavier SH, Mattos SS, Guedes AS, 1980. Catálogo da coleção de entomologia do Centro de Pesquisas René Rachou, Fundação Oswaldo Cruz. Gêneros Anopheles Meigen, 1818 e Chagasia Cruz, 1906 (Diptera, Culicidae). Ci Cult 32: 580-588.

Williams P 1993. Relationships of phlebotomine sand flies (Diptera). Mem Inst Oswaldo Cruz 88: 177-183.

Wirth WW 1974. Family Ceratopogonidae. In N Papavero, A Catalogue of the Diptera of the Americas South of the United States 14: 1-89, Museu de Zoologia, Universidade de São Paulo, São Paulo.

Wirth WW, Dyce AL, Spinelli GR 1988. An atlas of wing photographs, with a summary of the numerical characters of the Neotropical species of Culicoides (Diptera, Ceratopogonidae). Contr Am Ent Inst 25: 1-72.

Wirth WW, Ratanaworabhan NC, Blanton FS 1974. Synopsis of the genera of Ceratopogonidae (Diptera). Ann Parasit Hum Comp 49: 595-613.

Xavier SH 1973. Mosquito types of Brazil. Mosq Syst 5: 159-160.

Xavier SH, Mattos SS, Silva JE 1989. Mosquito types of Brazil - Supplement. Mosq Syst 21: 50.

Young DG, Duncan MA 1994. Guide to the identification and geographic distribution of the Lutzomyia sand flies in Mexico, the West Indies and South America (Diptera, Psychodidae). Mem Am Ent Inst 54: 1-881.

Young DG, Fairchild GB 1974. Studies of Phlebotomine Sand Flies, Department of Entomology and Nematology, University of Florida, Gainesville, $151 \mathrm{pp}$.

Zumpt F 1973. The Stomoxyine Biting Flies of the World. Taxonomy, Biology, Economic Importance and Control Measures, Gustav Fischer Verlag, Stuttgart, 175 pp. 